\title{
DISCOURSE ANALYSIS IN QUALITATIVE RESEARCH: NOTES FROM AN EXPERIENCE WITH HOMOEROTIC MICRO-TERRITORIALITIES
}

\author{
Alexandro da Silva* \\ Universidade Federal de São Paulo
}

Carlos Roberto de Castro e Silva**

Universidade Federal de São Paulo

\begin{abstract}
This article addresses discourse analysis as analysis methodology in the field of Qualitative Research and Geography. Recognizing that the possibilities of analysis in qualitative studies comprise multiple-dimension questions (epistemological, theoretical and technical), this study is based on an ethnographic research in a territory where the predominant circulation is of men who have sex with other men in order to propose dialogues and problematizations on concepts and research practices that intersect references of discourse analysis, geography of sexuality and the practices of analysis in the context of qualitative research. The results point to the possibility of using discourse analysis to analyze the geographic space (its limits and possibilities) while reiterating the need for a reflection on the way analysis methodologies demand more consistent appropriations in the use of academic studies.
\end{abstract}

Keywords: qualitative research, discourse analysis, territory, geography of sexuality.

ANÁLISE DE DISCURSO EM PESQUISA QUALITATIVA: NOTAS DE UMA EXPERIÊNCIAS A PARTIR DE MICROTERRITORIALIDADES HOMOERÓTICAS Resumo: $O$ artigo discute a análise de discurso como metodologia de análise no campo da Pesquisa Qualitativa e da Geografia. Reconhecendo que as possibilidades de análise em pesquisas qualitativas comportam questões de múltiplas dimensões (epistemológicas, teóricas e técnicas), o estudo parte de uma pesquisa etnográfica em um território cuja circulação predominante é de homens que fazem sexo com outros homens para propor diálogos e problematizações acerca de conceitos e práticas de pesquisa que interseccionam referências da análise de discurso, da geografia da sexualidade e das práticas de análise em contexto de pesquisas qualitativas. Os resultados apontam para a possibilidade de uso da análise de discurso na análise do espaço geográfico (seus limites e possibilidades) ao mesmo tempo que reitera a necessidade de uma reflexão sobre a forma como metodologias de análise demandam apropriações mais consistentes no uso de estudos acadêmicos.

Palavras chave: pesquisa qualitativa, análise de discurso, território, geografia da sexualidade.

\section{ANÁLISIS DEL DISCURSO EN LA INVESTIGACIÓN CUALITATIVA: APUNTES DE UNA EXPERIENCIA DESDE MICROTERRITORIALIDADES HOMOSEXUALES}

Resumen: El artículo discute el análisis del discurso como metodología de análisis en el campo de la Investigación Cualitativa y la Geografía. Reconociendo que las posibilidades de análisis en la investigación cualitativa involucran cuestiones de múltiples dimensiones (epistemológicas, teóricas y técnicas), el estudio parte de una investigación etnográfica en un territorio cuya circulación predominante es de hombres que tienen sexo con otros hombres para proponer diálogos y preguntas sobre de conceptos y prácticas de investigación que cruzan referencias de análisis del discurso, geografía de la sexualidad y prácticas de análisis en el contexto de la investigación cualitativa. Los resultados apuntan a la posibilidad de utilizar el análisis del discurso en el análisis del espacio geográfico (sus límites y posibilidades) al tiempo que reiteran la necesidad de reflexionar sobre cómo las metodologías de análisis demandan apropiaciones más consistentes en el uso de los estudios académicos

Palabras clave: investigación cualitativa, análisis del discurso, territorio, geografía de la sexualidad. 


\section{Introduction}

This article aims to discuss the possibility of using discourse analysis as analysis methodology in the field of qualitative research, in particular, focusing on human geography. To this end, we aimed at a research experience that sought to understand the territorialization processes of men who have sex with other men in a city on the Southern coast of São Paulo (SILVA, 2013).

The field of qualitative research comprises distinct epistemological, theoretical and methodological traditions, in which the specific historiography of each field of knowledge organizes for itself, in a dialogue between peers, the possibilities of operating the scientific making.

This diversity, and the vicissitudes of a novice researcher, not native to Geography, posed challenges along with the investigation process conducted and which we believe pertinent to expose, both to gather discussions and for the possible questions that may emerge from this experience report.

As we will see below, Discourse Analysis may be understood as a field of knowledge that emerged in the second decade of the 20th century, bringing a set of notions, techniques and a precise object, or an analysis technique used by Social and Human Sciences that comes from the adoption of epistemological care, especially in its instrumental adoption. In both perspectives, it is not possible to mention the imbrication that they maintain with each other. In this study, we sought to report the questions that emerged from the possibility of using discourse analysis as an information analysis technique, to analyze territorialization processes in the field of Geography.

As discussed by Turra (2011), the methodological analysis of this field, especially in human geography, incorporates techniques for surveying and analyzing other fields of knowledge. This process makes both the development of epistemological assumptions that guide the construction of techniques and the very original theories the study potent. Thus, addressing this discussion is part of the exercise for broadening the possibilities of geographical analysis, which, without the pretention of exhausting interpretative possibilities opposed to the discussion, is placed as a performed experience.

In this sense, the article goes through some clues that might help understanding the discussion. First, we will make a brief presentation of the research which led to the questions on analysis technique. This outline helps us understand the procedurality in research and how this occurred in our study. Then we will discuss the field of qualitative research and how the issue of information analysis technique cannot be understood as a simple instrumental application, without the need for understanding the ontological and epistemic incidents that impact the production of information and the intended theoretical development. Finally, we stop at the discussion on discourse analysis and the possibility of using it in the field of Geography. With this trajectory, we hope that readers might reconstitute their own level of understanding the proposal, contributing - from the raised reflections - to this endeavor.

\subsection{Contextualizing the research path that preceded the} adoption of discourse analysis as discussion reference

The research that originated the question on the possibility of discourse analysis to analyze the geographical space, starting from homoerotic microterritorializations, was developed in an interdisciplinary graduate program in Health Sciences. The initial proposal was to investigate how the experience of men who have sex with other men happened in a socially marginalized urban space, both by the presence of people with stigmatized behaviors and practices and by the territorial appropriation circumscribed to a city space with precarious urbanization.

The field that appears as a reference in the initial research is a semi-urbanized interval, with residential density processes around, of a strip of beach in a city on the Southern coast of São Paulo. Its regulars use the emic term areião to refer to that space.

The historical characteristic of non-urbanization and, at the time of the investigation, of semi-urbanization, consisted of a low incidence of urban furniture, residences, pavement and lighting; presence of native vegetation in deforestation process and circulation spaces consisting of the very subjects that use that space as spatial reference for several types of purposes.

The characteristic of marginalization of the space consisted both of the scarce urban structure of the place and of the frequency majority of men who have sex with other men (MSM), drug users, thieves, voyeurs (homo, hetero and bisexual) and exhibitionist heterosexual couples - these in a smaller quantity. The circulation of other publics consisted basically of tourists and residents who use the space as circulation point between two urbanized areas.

The insertion of the researcher in that field preceded the research experience, having contact with that space through health promotion activities, distributing condoms and dialoging about health with the regulars of that place. At no time we thought about the need to separate the 
figure of the subject who promoted health from the figure of the researcher, although both activities had distinct natures and demanded equally distinct strategies of perception, interaction and dialogue.

Thus, the initial propose for a research approach was to use ethnography as the technical dimension for collecting information. As technique, it assumed both observing the participant and the possibility of using other technical procedures, and, in the specific situation, we used semi-structured interviews and a socioeconomic questionnaire.

Ethnography was performed for 15 consecutive days, during the morning, afternoon and evening. The strategy to approach participants was "face-to-face" and "snowball," and the participation criteria were signing the informed consent form and being over 18 years-old, since the presence of adolescents was constant in that space. After these procedures, we continued with the interview and filling of the socioeconomic questionnaire. During the process of contacting the participants, 48 people were approached. Of these, 20 subjects accepted participating in the study; one subject accepted, but we had to stop the interview due to a situation of violence that could compromise our integrity; 20 denied participation in the study; four said they were there for drug use and 2 said they were on the trail, an emic term for the practice of theft.

Since it was a public, open space, we asked the participant to choose the place where he/she would feel more comfortable to talk.

At that time, at the beginning of the journey, the idea of working those processes through the concept of territory was more due to how it was read by the field of health, by the way the singularities of an area of care appropriated from a concept from another field, than properly from the field of Geography. This condition was evidently linked to the graduate program in which we participated, but, above all, to the fact that we are not native to the discipline of Geography.

However, the discursive limits of the initial approach forced us to broaden the references for this discipline and the category of geographical space, through its main concepts, and it gradually produced mutations both in the way ethnography was used and in the research project as a whole. The need for rigor parameters, as pointed by Turra (2011) and Nakamura (2011), was noticed both by the effort to keep levels of coherence between the scales of analysis (epistemological, ontological and technical) and by the appropriation of Geography concepts, maintaining this same coherence.

All these questions, thinking of a research path that was modified by the contact with the field, led us to make a reflection exercise on the indeterminations of qualitative research and the possibilities of building information from this characteristic. In general, this is the exercise shown below.

\subsection{Qualitative research and knowledge production}

Without intending to expose an exhaustive analysis of what we observed in the texts of heterogeneous disciplines, which claim discussions from a qualitative perspective, it is possible to say that there are competing interpretations on the constitution of the field of qualitative research (SILVA, 2018). Basically, we might summarize them as:

a) a field of questions, theories and practices, within the scientific field, which emerges from the limits of the quantitative field, especially for objects whose nature extrapolated the experimental-statistical logic of analysis. This interpretation was based on the questions raised by Thomas Khun (2003), when he reflects on the limits of the scientific field, within what he considers as normal science;

b) another field of questions and practices that emerge not from the limits of the technique, but from the historical-cultural changes that allow changing the conception of objects. In this field, the atomistic gaze progressively gives way to the spectral gaze. In this way, we observed the change of perspective both in the possibility of thinking the objects and the references that create these objects for science. Several authors study this perspective, but we signal Souza Santos (1988), Foucault (1999) and Feyerabend (2011) as representatives of the group of authors that study the turning point of the technical emphasis on science, its discourse and establishment as historical, political, economic and social reference.

This summary, with all the limits it contains in its formulation, might help us to understand the multiplicity of places from which we may think the field of qualitative research. Although, as historical experience, it shows traces in the early days of the constitution of the scientific field, and Foucault (2004) shows this well when he records the mutation of the medical sciences between the 18th and 19th centuries, its constitution as field consolidates from the beginning of the 20th century.

This consolidation was processed multiple and asynchronously not only by the rupture with the traditional canon of doing science, but especially by monitoring the development of social and human sciences. New disciplines of knowledge demanded new techniques 
of reading, surveying and analyzing its objects. This explosion of possibilities and crosses generated, from the epistemological, theoretical and methodological point of view, two perspectives that developed parallel in the qualitative field: assimilationism and (epistemological and technical) rupture, respectively.

By assimilationism, we refer to the conservation of formal logic, especially in its technical parameters of scientific making, implicated in the forms of survey and analysis of information for the production of knowledge.

In this logic, although the objects were understood in their spectral dimension, disperse in multiple possibilities of comprehension, the comprehension models of these characteristics were linked to the technical monism and to the constitutive invariance of the objects.

Going from technical monism to formal comprehension was a matter of intellectual situated trajectory, remembering, from Bourdieu (1983), that the field of qualitative research was developed parallel to the hegemonic field of quantitative research.

For Bourdieu (1983), the notion of field ends the dispute of spaces between agents and institutions for the production of hegemonies and subalternities, and their actors have symbolic, economic and/or social capitals that allow them to remain in this tension.

If we think the process of irruption of qualitative research within the centers of scientific development, it is plausible to understand the function of assimilationism in these conditions. In the dispute for spaces, legitimation and especially financing, the total rupture with the traditional modus operandi of science would not be an unscathed and inconsequential process. In order to continue to belong to that community of origin, it seems to us that understanding elements of traditional logic of making science should be present to legitimize their possibility to think both non-traditional objects and the diversity of perceptions on objects.

As for rupture, we can think of production processes of scientific knowledge that introduced not only new ontological, epistemological and theoretical perspectives, but, above all, the technical and procedural dimensions in the production of this knowledge.

The dispersion of the procedural and technical arsenal was a fundamental factor for the development of qualitative research, especially if we think about the cyclical possibilities of experimentation and expansion that this development implied for the set of references that preceded its initiatives and choices. Alongside this, the ethical-political impact of this development was not socially despised.

The changes brought about by new knowledge from such diverse fields, capable of causing new readings on seemingly stratified issues, corroborated with a certain breath of qualitative research. If, in the space of disputes between fields, it is considered for many, when it does not resort to formal logic, an aesthetic-philosophical, nonscientific field, its political and social impact contributes to its maintenance in the academic field.

Generally, both assimilationism and rupture converge for the multiple production of the field of qualitative research. This constitution is perceived both internally, by the community of practitioners of this type of research, and externally, by quantitative researchers, especially in what it situates-one to the other and between each other-its places within scientific making. For this article, in particular, we were interested in internal clashes and its implication for the legitimation between peers of the qualitative research process.

As an example, regarding the criteria of judgement and legitimation of scientific studies, two authors may help us reflect on what we call assimilationism and rupture in qualitative research. To this end, we resorted to Demo (1998) and Péres-Abril (2009). Our aim with this discussion, which will not deepen the dialogue made by its authors in their original articles, is to point out the issues that illustrate some points of internal dispute while helping us to understand the implication for the quantitative research in Geography.

Both authors become iconic from the assimilation and rupture movement when discussing the legitimacy of qualitative research. While Demo (1998) observes the need for a formalizing movement for the production of a qualitative research that may be backed by scientific parameters, Pérez-Abril (2009) problematizes the technique as a base of these parameters, introducing the discussion on ontological and epistemological foundations that make this technique, or form, as a privileged point on which scientific legitimacy is based.

For Demo (1998), the issue of quality, in particular because of this tangential, eminently ethical-political nature, could not have a treatment, an approximation, that only sought the contours of the phenomena. For the author, the search for the sensitive dimensions of phenomena should suffer a continuous process of reflection and improvement of the steps, processes, procedures and techniques for surveying and analyzing phenomena.

His discussion leads us to the issues of separation between scientific knowledge and common sense, without opposing them in terms of importance, but signaling the need for a place of production guided by knowledge processes that would justify the internal differentiation between the two. Demo signals that the technical improvement is as necessary for qualitative 
research as for quantitative research, although with distinct emphasis. His criticism on the adoption of procedures only for the consecrated or the lack of investment in their development and problematization fatally leads us to circular research projects, since the theoretical construction derived from them may be originally flawed, which is little problematized in the academy. For example, he mentions his own quantitative research in which the continuous improvement of procedures and techniques allowed the recognition of its limits of knowledge.

Pérez-Abril (2009) conducts the discussion on the legitimacy of qualitative research by another route. For the author, the dispute on technical monopolies that structure scientific knowledge in this group make opaque a research that, for him, would be central in this specific production: the conditions that allow the centralities and peripheries of certain technical discourses and their impact both on the internal dispute of the field, among fields, and their ethical-political place in the social constitution.

His contribution follows the discussion on how monopolies of political power internal to the scientific community interfere or not in decisions on what emerges as legitimate in each field. In this sense, even thinking of fields and their internal disputes, ontological, epistemological and technical monopolies have their improvement already circumscribed in their origin, opening little space to a real understanding of development.

For the author, the questions, instead of being asked to the techniques, should be asked to the discursive possibilities of the scientific field that allow their establishment, legitimation and validity. This, in addition to making possible a real understanding of these means, would also make clear not only its author - when using it - but also the conceptual, ontological, epistemological and social addressing that this use contains.

In general, with their crossings and dissonances, these questions configure the field of qualitative research and become eligibility criteria for legitimate and/or valid knowledge from an academic point of view.

As Bosi (2012) indicates, our cultural tradition does not enable us to discuss the academic development process, from elementary school to university. For the author, the current criteria of academic production do not deepen the surrounding and fundamental dimensions of this specific doing, and, even within the same field, we observe many times what she calls Tower of Babel, or the profusion of perspectives that, even belonging to the same tradition, cannot converge minimum elements of communication; consequently, we would have an exponential development (whether theoretical, technical or methodological) that does not allow exchanges, comparisons, contradictory and development - thinking of a supposed field unit.

Thinking about the trajectory of the developed research, these were the questions that, at the time, emerged in face of contact with the field. The dialogue with participants, the observations of circulation, the representations on the special networks involved in that particular appropriation, all these - and other - questions forged an instability of assumptions that demanded the search and appropriation of theoretical references linked to the research processes and to the field of Geography.

This appropriation, in addition to expanding the understanding on the initial idea of the research, posed other questions: how to analyze the information we had access to? What references would better answer that peculiar study? Here we are at the moment of reporting the construction of discourse analysis as a possibility of analytical moment of the geographic space.

\section{Space and Discourse: materials and methods}

Problematizing discourse analysis as a possible analysis methodology to analyze microterritorialization processes sterns from a concrete research experience, in which discourse is considered an object and analytical device (ORLANDI, 2012). In this sense, this experience report collides with four movements of information collection that are concomitantly intersecting:

1 - the analysis of the trajectory of a research project in which the methodology of information analysis (discourse analysis) mobilizes a discussion about its relevance, as a technique and object, and the coherence with the elements found in the field and the concepts of the field of Geography;

2 - in the field of technique, within a qualitative research, the definition of analysis methodology;

3 - the possibility of the field of discourse analysis in the interpretation of the relations that involved spatial proceduralities; and

4 - the gestures of interpretation that would allow the discourse analysis from geography of sexuality concepts and the relations experienced in the field of research.

As a whole, these movements to survey and analyze information bring elements from a concrete research experience, internal elements of discussion that supported the methodological choices of that experience (collecting information on qualitative research) and the deepening of the discussion through the information analysis device.

The understanding that there are comprehension 
scales based on the discourse of the participants themselves at the same time that micro-processes of territorialization posed questions/concerns linked to the forms of construction of a comprehension that did not address the intersections of these scales, since the discourse was a mediation that marked both scales.

According to Schutz (1970):

The subject's narrative is it always marked by their particular perspective and does not contain the total truth about the phenomena under study. Therefore, understanding is not only to seek the subject's intentions nor passively contemplate their speech or action, since this does not stop in the conjuncture in which they live, neither are their thoughts and social insertion mere fruits of their will, personality and desire. (GADAMER, 2003, apud MINAYO \& GUERRIERO, 2014, p. 1106, our translation)

3. Discourse Analysis and concepts of the field of Geography: results and discussion

\subsection{Discourse analysis}

As Orlandi (2012) points out, discourse analysis (DA) is a theoretical and methodological field that, although it may be recognized sparsely before this, has its systematized organization period from the second half of the 20th century. It is important to highlight that, as a diffuse field, we are working with authors that are usually grouped under a tradition linked to France, or the French school, recognized by its less pragmatic brand when compared to the American discourse analysis.

As a field, the theoretical discussion of discourse analysis is born from the confluence, without being confused with them, between three other fields: linguistics, dialectical historical materialism and psychoanalysis. Without deeply addressing this discussion, it is important to say that the theorists of discourse analysis recognize epistemological, theoretical and technical possibilities in language as mediation between reality and the subject, the role of history in the forms of social construction and the recognition of unconscious dimensions of human activity.

Its particular articulation by DA inserts it into the rupture movement with the qualitative research models in force at that time. Through the concept of discourse, which is not synonymous to language or speech, it was possible to rearticulate parameters of information analysis that expanded the possibilities of interpretation hitherto in force.

Foucault, in Madness and Civilization (1961), is one of the epistemologists that brings the discourse as an object capable of evidencing the mobility of power systems by showing the displacement of meanings attributed to insanity in time and space, alongside its normative and singularizing function of individual and social experiences.

This definition is quite important because it highlights one of the most important marks of DA: its reticular characteristic that supports (and is supported by) diffuse force strategies. In this sense, discourse is the mechanism that supports the proposition of any language, whether it is language, symbol, architecture, science, interpretation, and, in our perception, space.

There is commonly the impression that discourse is a synonym of language, however, although also encompassing it, discourse goes beyond it; because discourse, to be expressed, demands a symbolical formation that will operate the language mediations from which force relations will be stabilized.

Unlike Content Analysis (CA), DA does not work with the notion of language transparency, that is, social meanings and personal senses expressed by a speech or architectonic language, for example, are not possible to be understood only by the analyst's gestures of interpretation.

There is a history (of language, subject, context and of relationships) that requires a work by the researcher beyond recognizing more immediate senses and meanings provided by the context, in general, supported by the analyst's repertoire.

The mediation used (language, symbol, concept, territorialization, spatialization, comprehension, feeling) is the source of questioning for the researcher, since their interpretation gesture places that choice (mediation chosen by the subject) both in its apparent form and in the movements of forces that affect and support that choice.

In DA, everything that is expressed may be expressed otherwise. This comprehension is important to draw our attention to the openness of the language (ORLANDI, 2012b). There would be no a priori meaning from which all the other meanings and senses would maintain a contingent relation of approximation. Both the approximation and removal movements of meanings are more linked to the subject's particular dynamics - considering their insertion into scales of different experiences, relationships, time and space - than to a priori contents they may have. This results from one of the analytic procedures in DA: the desuperficialization of discourse.

To study the desuperficialization of discourse is to undo the referential illusion that discourse originates from the subject (ORLANDI, 2012a), that is, that there are 
no forces (immediate, mediated and/or unconscious) acting on the construction of discourse. In this sense, the task of studying other possibilities of implying that discourse/subject in other networks of meanings implies the analyst in other relations of forces. The comparison between these relations contributes to the understanding of mechanisms that operate a particular expression and not another equally possible.

\subsection{Geographical scape and discourse analysis: approximations made}

In DA, analytics is procedural and seeks to bring to the interpretive scene several movements that constitute the possibility of that specific discourse. In this procedure, what was not said, what could have been said otherwise, among other movements, is incorporated to the analysis so that the researcher may situate the discourse in question. If desuperficialization helps them to work the referential illusion of the subject as the origin of the discourse, a procedure that had the same effect in relation to themselves would be necessary, that is, a procedure that would decentralize them from the place of inductor of senses and meanings to the reading of those discourses, based on their unique or expert experience.

This decentralization of place, as a privileged reader/ researcher, is placed on operating the understanding of the intersection between interdiscourse and intradiscourse; interdiscourse is a dispersion of senses, meanings, practices, symbols, etc., that mark the possibilities of the historical enunciation of a discourse-remembering that a discourse is never free, although the referential illusion is one of the conditions for its emission as volitive act. According to Orlandi (2012a, p. 31), interdiscourse is "defined as what is said before, elsewhere, regardless. That is, it is what we call discursive memory: the discursive knowledge that makes possible every saying and that returns in the form of something pre-built, the already said is at the base of the sayable, supporting each word said" (our translation). Intradiscourse is the sense regimented by the immediate experience of the subject, what they can, from their experience, point out as reason for their position.

In discourse analysis, the analytics that comes from discourse intends to recover the set of elements that focus on stabilizing a discursive formation, a specific inscription of saying, and how, from this, the subjects' positions, historical marks, materiality, ideologies and forgetfulness are revealed.

For Pecheux (2002) and Orlandi (2012a), it is the theoretical references that would ensure the possibility of this removal regarding the analyst/researcher. According to these authors, without letting these predecessor references immobilize the reading of the phenomena raised in the field, since, in this case, there would be no advance, but repetition, theoretical references contribute to understanding the positionality of the researcher when broadening their original perception, both particular and theoretical.

In the research performed, contact with participants, the peculiarity of that territorialization process, the access to discourses, the observations on how they experienced a discontinuous spatiality, required a sui generis theoretical approximation.

It was in this concrete movement of researching that Geography of gender and sexuality was gradually incorporated as articulating axis of the study. The immersion in this specific approach of human geography also required a previous reading on the main concepts that configure the possibility of understanding the geographical space, namely: space, territory, landscape and place.

In an ethnography, there is the concern to broaden the reading possibilities about specific phenomena, typical of groups, communities, among other possibilities. In this sense, the perception that that form of spatiality production was not fixed, nor linear, was supported by references such as Haesbaert (2007), who, from the concept of territory, understands it as a concept-process, incorporating material and immaterial elements to think about how this concept may help us read spatiality.

Thus, territorialization processes of men who have sex with other men gained important analytical layers. Issues such as the networked territorial formation, the consideration of points between circulation trajectories, socioeconomic dynamics for the definition of centralities and marginalities and the meanings of spatialization for the research participants reorganized our readings.

With these references more delineated, another step would be the approximation with authors who, in Geography, made the specific discussion in the field of gender and sexuality. It was then that the studies by Silva (2009) and Costa (2010a, 2010b, 2011, 2012) contributed to the circumscription of concepts and theoretical discussions that helped us to understand those processes.

Costa (2012) specifically, when discussing the territorial appropriations of men who have sex with other men, circumscribed by material and immaterial elements, helped us to shift the displacement of understanding that discourse and space are different analytical entities. When discussing homoerotic micro-territorialities, the author shows us that the territory itself is a discourse, and the discourses about it are spatial circumscriptions. 
According to the author:

Micro-territoriality is applied to this, in the case of this text, the territorialization of homoaffective and/or homoerotic coexistences in smalls parts (appropriation) of the social space: on one hand, this (micro) territoriality implies the representation or current norms and standards, thus the territorial existence as control of deviants; on the other hand, it represents the delimited space of authenticity, as a refuge or an island of relational authenticity among the objective perspectives of the social world. (COSTA, 2012, p. 258)

The discourse-space imbrication of homoerotic microterritorializations was revealed in the ways the participants' discourses contributed to understanding that territorial appropriation and how this appropriation contributed to the discursive formations we accessed. The movements of analysis that initially came from participants, through the discourses on those territorialization processes, incorporated the space as a socially built discourse that instituted the discursive borders elaborated by the participants.

The theoretical referential that outlines the discussion on gender and sexuality in the field of Geography and, in particular, homoerotic microterritorializations, allowed us to access the imbrication mentioned above. Listening the participants' discourses may only be analyzed in the constitution of the interdiscourse and intradiscourse as the process of micro-territorialization itself was translated into a discursive element, anchored to the experiences of the segmented territorializations of those participants.

Since intradiscourse indicated the incidence of a set of normative prescriptions on gender and sexuality in the constitution of the positionabilities of those subjects in face of those territorial appropriations, interdiscourse revealed discursive marks that were linked to territorial anchorage, although, in the access to the discourses that came from the subjects, these marks seemed anchored only in their perception. As an example, we will show some of the elements of these analyses below.

\subsubsection{Experience of central and peripherical micro-} territorializations regarding the experience of sexuality

In the context of the conducted research, in which the possibility of a homoerotic experience occurred, it was possible to observe two levels of incident elements:

1) the concrete territorial constitution itself, limited by urban occupation boundaries that were distinguished from their outer contour, from the urbanization of the city and the region as a whole.

This constitution, linked to processes of market interest of the space in question, was not included in the discursive production of the research participants. The concrete limits were read as natural, whether as a necessary mark of opposition between sexual practices diverting normative sexuality, between distinct territories, or as a space for recomposing an agency linked to the sexuality that could exist there.

A set of accessed discourses linked that microterritoriality to a historical lapse of the heteronormativity that organized the spaces and unfolded in the perception of an idyllic experience of the territory. Reports on the territory being seen as a paradise, as inducer of relationships, of well-being, of belonging, competed with the structural reality of a place with almost no urban intervention (furniture, accesses, etc.), without lighting, without public security and with a circulation marked by conditions adverse to the population as a whole and to that specific public.

As real estate interests started to press that territory appropriation, intradiscourse was put in motion through expressions that denoted change processes linked to the decrease in circulation spaces within the Areião itself. New micro-territorialities were outlined as a way to reduce even more the circulation scale, already circumscribed, in an attempt to maintain an appropriation operating especially through discourses.

In internal confrontations, sex on the street, which was previously naturalized in that context, is now poorly seen since it strips to new passers-by the nature of the sexualized relationships that took place there. A new ethics begins to regulate relationships without the broader incidences going through the interdiscourse of those subjects. Among themselves, the subjects begin to attribute value to sexual practices that are more invisible within the territory: the more open sexual exposure was, previously valued as a reaffirmation of a natural appropriation, the more the activation of moral interdiction was used as a form of internal control for the advancement of space reduction.

2) the discursive production that was composed of experiences, prescriptive-normative incidences and desire.

The territorial outline marked by distinct experiences between the inside and the outside of the Areião revealed a set of discursive formations that articulated possibilities of understanding that imply plurilocalized subjects (ROSE, 1993).

For Rose (1993), it is not possible to think of a one- 
dimensional subject who is equal to him/herself in any space and relationship. Subjects may, depending on the established relations with alterity and space, relate differently with these incident scales.

This understanding was evidenced by the discursive formations that composed different possibilities of behavioral expression, ways of relating and even to present themselves to others from the mediations that articulated, axially, spaces and normative prescriptions linked to gender and sexuality.

Such discursive formations, expressed through the notions of boundaries between territories, through the production of tension and relief regulated by relationships of different natures, produced distinct types of spatiality that were at the same time marked by notions such as permission, interdiction and permeabilities, had territorial lines that placed the subjects and their positionality beyond the desire(s) that were reported as singular.

This was, among others, an important way of understanding how the notion of discourse, and the possibility of something analytical within a specific field of discussion, that allowed a dialectical analysis between positionalities of subjects and marginal microterritorialization, taking as reference the normative experiences of the central spaces in symbolic relationships.

Compulsory heteronormativity (BUTLER, 1999) does not impact only on the production of social and individual identities, revealing itself as an important spatial marker in the delimitation of spaces.

The way the research participants dealt with the dynamic desire-expression-space, translating plurilocalizations through territorial permeabilities and interdictions, was anchored both to interdiscourses (normative notions of sexuality, violence etc.) and intradiscourses (desire, reasons that justified a territorial experience based on different questions, behaviors and experiences between their spaces of circulation).

Although the discourses translated singular experiences, the analytical moves enabled by discourse analysis allowed the discussion of a relationship (subject and society), articulating the incidence of multiple scales (historical, personal, spatial, relational, among others). This possibility creates a condition for analytics that intends to be multidimensional, even though we understand the limits that any analysis device contains.

In the specific research experience, discourse analysis contributed to broadening the field of questions and specific conditions of the topic, at the same time it allowed us to deepen the knowledge and possibilities of using the analysis device in question. 


\section{Referências}

BOSI, M. L. M. (2012) Pesquisa qualitativa em saúde coletiva: panorama e desafios. Ciência e Saúde Coletiva, Rio de Janeiro, n. 3, v.17, p. 575-586.

BOURDIEU, P. (1983). Algumas propriedades do campo. In: Bourdieu, Pierre (1983) Questões de Sociologia. Rio de Janeiro: Ed. Marco Zero.

BUTLER, J. (1999) Corpos que pesam: sobre os limites discursivos do "sexo". In: LOURO, G. L. (org.) O Corpo educado: pedagogias da sexualidade. Belo Horizonte: Autêntica.

COSTA, B. P. (2010a) Espaço social, cultura e território: o processo de microterritorialização homoerótica. Espaço e Cultura, UERJ, RJ, n. 27, p. 25-37

COSTA, B.P. (2010b) Geografias das representações sobre o homoerotismo. Revista Latino-americana de Geografia e Gênero, Ponta Grossa, n.1. v.1, p. 21-38.

COSTA, B.P. (2011) Geografias, masculinidades e homoerotismo: teorias, práticas e posicionalidade de pesquisa. In: SILVA, J.M.; ORNAT, M. J.; CHIMIN JR., A.B. (orgs.) Espaço, Gênero \& Masculinidades Plurais. Ponta Grossa: Todapalavra, COSTA, B.P. (2012). As microterritorialidades nas cidades: reflexões sobre as convivências homoafetivas e/ou homoeróticas.Terra@Plural, Ponta Grossa,n.2, v.6, p. 257-271.

DEMO, P. (1998) Pesquisa qualitativa: busca de equilíbrio entre forma e conteúdo. Revista LatinoAmericana de Enfermagem, Ribeirão Preto, n. 2, v. 6, p. 89-104.

FEYERABEND, P. (2011). Contra o método. Tradução de Cézar A. Mortari. São Paulo: Editora Unesp

FOUCAULT, M. (1979). Sobre a história da sexualidade. In: Foucault, M. Microfísica do poder. Rio de Janeiro: Edições Graal.

FOUCAULT, M. (1999) As palavras e as coisas. Uma arqueologia das ciências humanas. Tradução de Salma Tannus Muchail, $8^{a}$ edição. São Paulo: Martins Fontes

FOUCAULT, M. (2004) O nascimento da clínica. São Paulo: Editora Forense Universitária

GADAMER, G. (2003). Verdade e Método I - Traços fundamentais de uma hermenêutica filosófica, $5^{\mathrm{a}}$ ed. Rio de Janeiro: Vozes

HAESBAERT, R. (2007) Identidades territoriais: entre a multiterritorialidade e a reclusão territorial (ou: do hibridismo cultural à essencialização das identidades). In: ARAUJO, F.G.B. \& HAESBAERT, R. (orgs.) Identidades e Territórios: questões e olhares contemporâneos. Rio de Janeiro: Access.

KHUN, T. (2003) A estrutura das revoluções científicas. 7. ${ }^{\text {a }}$ ed. São Paulo: Perspectiva.

MERCAdo-MARTINEZ, F. J. (2011) Pesquisa qualitativa em saúde: desafios atuais e futuros. Texto e Contexto Enfermagem, Florianópolis, n. 4, v. 20, p. 645-646.

MINAYO, M.C.S; GUERRIERO, I.C.Z. (2014) Reflexividade como éthos da pesquisa qualitativa. Ciência \& Saúde Coletiva, Rio de Janeiro, n. 4, v. 19, p. 1103-1112. Available from: http://www.scielo.br/scielo.php?script=sci_ arttext\&pid=S1413-81232014000401103. Access on: April 11, 2019

NAKAMURA, E. (2011) O método etnográfico em pesquisas na área da saúde: uma reflexão antropológica. Saude soc. [online]. 2011, vol.20, n.1, pp.95-103. Available from: http://www.scielo.br/scielo.php?pid=S0104$12902011000100012 \&$ script=sci_abstract\&tlng=pt. Access on: March 11, 2019

ORLANDI, E. P. (2012a) Análise de discurso: princípios e procedimentos. 10ª edição. Campinas, SP: Pontes Editores.

ORLANDI, E. P. (2012b) Discurso em análise: sujeito, sentido e ideologia. Campinas, SP: Pontes Editores.

PÊCHEUX, M. (2002) O discurso: estrutura ou acontecimento? Tradução de Eni Puccinelli Orlandi. $3^{\mathrm{a}}$ edição. Campinas, SP: Pontes

PÉREZ-ABRIL, M. (2009) A propósito de la legitimidad em la investigación cualitativa. Magis: Revista Internacional de Investigação em Educação, Bogotá, v. 1, n. 2, p. 235-248

ROSE, G. (1993) Feminism and geography. Polity Press: Cambridge

SILVA, A. (2013) Processos de territorialização em espaços marginais: estudo exploratório e descritivo das vivências de homens que fazem sexo com outros homens na cidade de Praia Grande/SP. Santos. Dissertação (mestrado) Universidade Federal de São Paulo, campus Baixada Santista. Programa de Pós-Graduação Interdisciplinar em Ciências da Saúde.

SILVA, A.; CASTRO E SILVA, C.R.; MOURA, L. (2018) Pesquisa qualitativa em saúde: percursos e percalços da formação para pesquisadores iniciantes. Saúde Soc., n. 2, v. 27, p. 632-645.

SILVA, J.M. (2009) Geografias feministas, sexualidades e corporalidades: desafios às práticas investigativas da ciência 
geográfica. In: Silva, J. M. (org.) Geografias Subversivas: discursos sobre espaço, gênero e sexualidade. Ponta Grossa, PR: Todapalavra

SILVA, J. M. (2009) A cidade dos corpos transgressores da heteronormatividade. In: SILVA, J.M. (org.) Geografias Subversivas: discursos sobre espaço, gênero e sexualidade. Ponta Grossa, PR: Todapalavra.

SOUSA SANTOS, B. (1988). Um discurso sobre as ciências na transição para uma ciência pós-moderna. Estud. Av., n.2, vol.2, São Paulo.

TURRA, N. N. (2011) Metodologias de pesquisa para o estudo geográfico da sociabilidade juvenil. RA'EGA, Curitiba, n. 23, p. $340-375$. 